\title{
Cerebellar Single Metastases from Bladder Transitional Cell Carcinoma: A Case Report
}

\section{Metástase cerebelar única secundária a câncer de celulas transicionais de bexiga: relato de caso}

\author{
Paulo Valdeci Worm ${ }^{1,2,4}$ Guilherme Finger ${ }^{2}$ Renan Desimon Cabral ${ }^{3}$ Jorge Luiz Kraemer ${ }^{4}$
}

${ }^{1}$ Graduate Program in Medicine: Surgical Sciences. Universidade Federal do Rio Grande do Sul, Porto Alegre, RS, Brazil

2 Neurosurgery Department, Cristo Redentor Hospital, Porto Alegre

Address for correspondence Guilherme Finger, MD, Department of Neurosurgery, Hospital Cristo Redentor, Porto Alegre, Rio Grande do RS, Brazil

${ }^{3}$ Urology Department, Hospital de Clinicas de Porto Alegre, Porto Alegre, RS, Brazil

${ }^{4}$ Department of Neurological Surgery, São Jose Hospital, Santa Casa Hospital Complex, Porto Alegre, RS, Brazil

Arq Bras Neurocir 2016;35:148-151.

\begin{abstract}
Keywords

- urothelial carcinoma

- cerebral metastases

- transitional cell carcinoma

\section{Resumo}

Palavras-chave

- carcinoma urotelial

- metástase cerebral

- carcinoma de células transicionais

Cerebral metastasis is the most common cancer in the Central Nervous System (CNS); however, the bladder is a rare primary origin. The incidence of bladder metastases to the brain tissue has slightly increased in the past decades, with a few case reports published in medical literature, but not in Brazil. The authors describe a case of a female with prior diagnosis and treatment of transitional cellular cancer, without signs or symptoms of local or disseminated relapse, who suddenly developed clinical signs of cerebellum impairment. The patient was submitted to neurosurgical procedure with good outcome, followed by oncologic adjuvant treatment.

As metástases cerebrais são as patologias neoplásicas mais comuns no sistema nervoso central (SNC), contudo, o epitélio vesical é um sitio primário raro para os tumores que acometem o parênquima cerebral. A incidência do envolvimento cerebral em tumores de bexiga tem aumentado nos últimos anos, com alguns relatos de caso descritos na literatura médica, contudo nenhum caso foi descrito no Brasil. Os autores relatam o caso de uma paciente com diagnóstico de câncer de células transicionais cujo sítio primário já fora tratado previamente, sem sinais de recidiva local ou à distância, que subitamente iniciou com sinais clínicos de síndrome cerebelar. A paciente foi submetida a ressecção cirúrgica da lesão com boa evolução pós-operatória complementada com terapia oncológica adjuvante.
\end{abstract}

\section{Introduction}

Transitional cell carcinoma (TCC) constitutes the most common bladder tumor, usually diagnosed as a superficial lesion localized in the urothelial layer without systemic spread.
However, metastases are frequent in detrusor-invasive cancer, occurring in $50 \%$ of patients. ${ }^{1,2}$

Among the possible sites of metastases, CNS is one of the least frequent tissue, and only occurs as a late event in the natural history of the disease. Cerebral evolvement is even received

October 11, 2015

accepted

March 27, 2016

published online

May 4, 2016
DOI http://dx.doi.org/

$10.1055 / \mathrm{s}-0036-1583936$ ISSN $0103-5355$.
Copyright $\odot 2016$ by Thieme Publicações License terms

Ltda, Rio de Janeiro, Brazil
(ब) $\Theta \circledast$ 


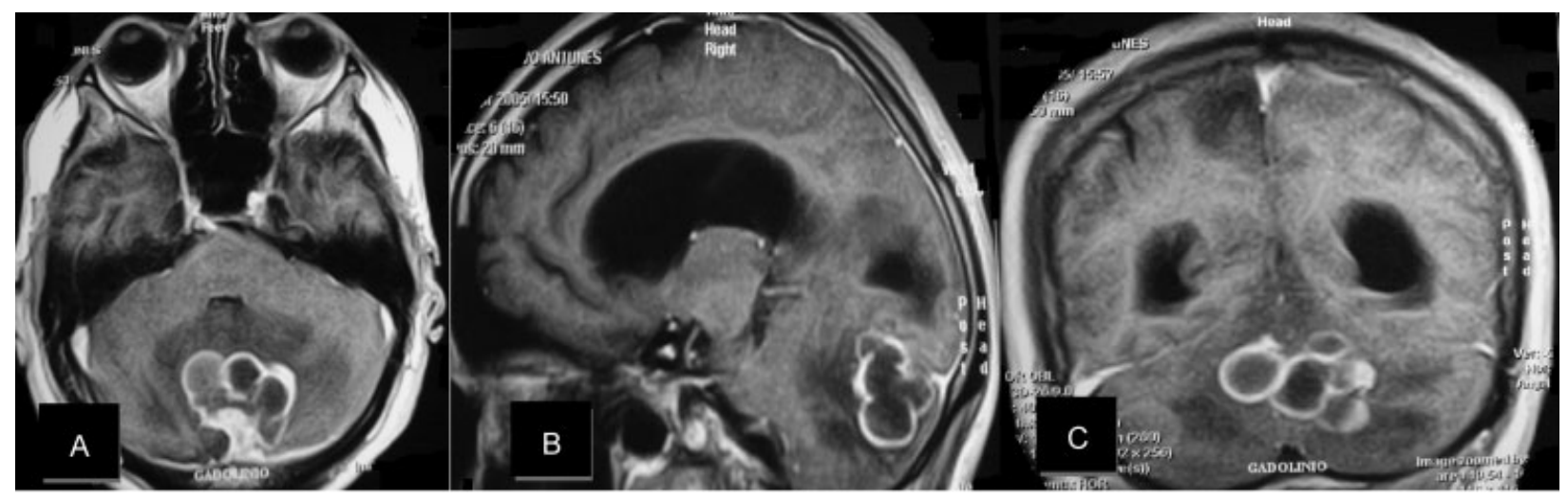

Fig. 1 Single cerebellum metastases seen in MRI enhanced by gadolinium. (A: axial view; B: sagittal view; C: coronal view).

rarer in patients with systemic controlled disease, without signs of relapse in lungs or liver, for example.

This is a case report of a patient with previous diagnosis and treatment of TCC who developed a single cerebellar metastasis, without involvement of other organs, and was submitted to surgical resection with good outcome and forwarded to oncologic adjuvant treatment, with a good survival follow-up.

\section{Case Report}

A 72-year-old Caucasian woman, with a medical history of bladder carcinoma treated surgically two years earlier and without signs of local tumor relapse, according to periodic cystoscopy during follow-up, suddenly started with intermittent headache and dizziness. The patient had been complaining about these symptoms for two months, and denied previous head trauma or drug abuse. She searched for neurological evaluation, and her neurological exam showed signs of cerebellar impairment (loss of balance, dysmetria

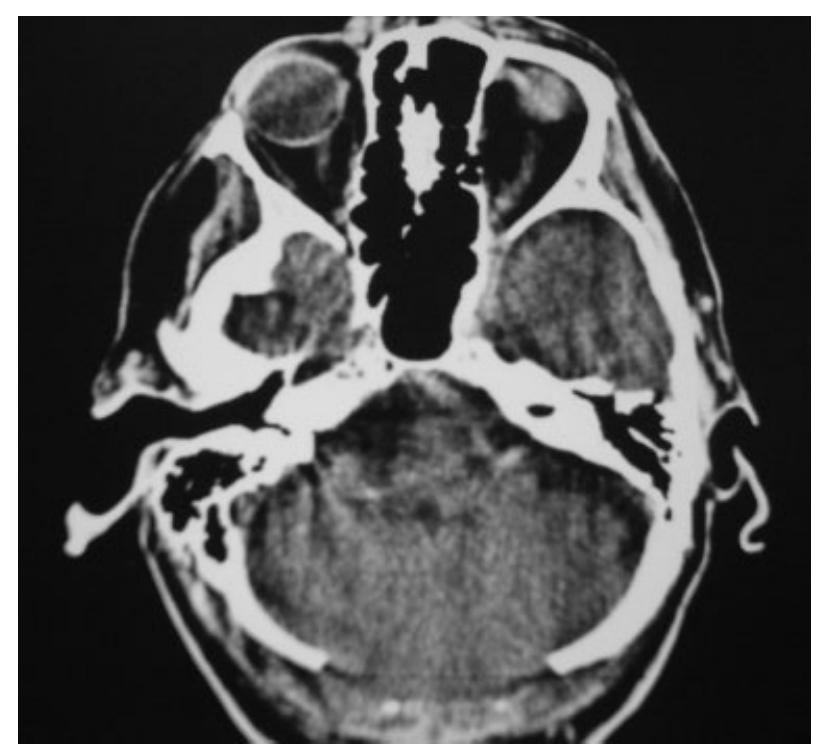

Fig. 2 Post-operatory Computed Tomography scan showing a macroscopically complete tumor resection. and dysdiadochokinesia) mainly in the right arm associated with bilateral papilledema. We performed a magnetic resonance (MRI) of the brain, which showed a tumoral lesion with expansive characteristics in the posterior fossa enhanced after gadolinium infusion (-Fig. 1). We indicated surgical procedure to remove the tumor (-Fig. 2), and controlled post-operatory intracranial pressure with a monitoring catheter placed in the left cerebral ventricle.

The tumor size was $5 \times 4 \mathrm{~cm}$ and located in the cerebellar vermis. Macroscopically, it had a light gray color, with a friable texture, and a bleeding infiltrating pattern, involving local venous drainage. Anatomopathological analysis diagnosed the tumor as undifferentiated large cell carcinoma, consistent with metastases from urothelial bladder carcinoma/transitional cell carcinoma (-Fig. 3 ). During the postoperatory period, the patient developed intracranial hypertension. We performed a ventricle-peritoneal bypass 10 days after primary surgery. After this second procedure, the patient recovered neurological and clinical status, receiving hospital discharge. We performed patient follow-up for 20 months, when the patient died from systemic complications of extra cranial tumor return.

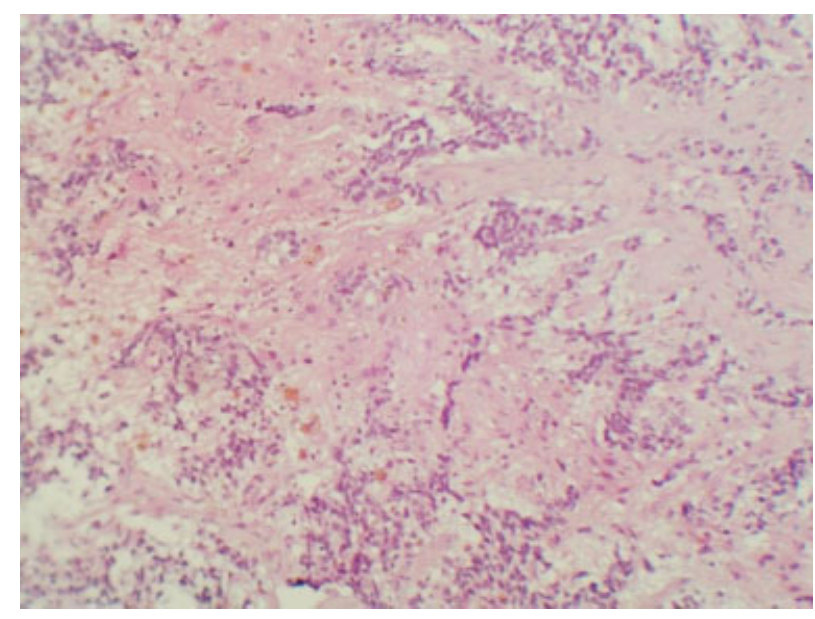

Fig. 3 Metastasis of poorly differentiated carcinoma in cerebellar parenchyma (hematoxylin-eosin). 


\section{Discussion}

Distant TCC metastases are related to the depth of penetration by the tumor into the muscular wall, and the most common sites of metastatic spread are regional lymph nodes, lung, and bones. ${ }^{3,4}$ Other common metastasis sites include liver, adrenal gland, and intestine. ${ }^{5,6}$ Intracranial metastasis in this context was first described by Lower and Watkins in $1924,{ }^{7}$ and, although it remains an infrequent clinical manifestation, the number of central nervous system lesions from bladder cancer has increased since $1980 .^{8}$

When the CNS is involved, it frequently occurs as a late event in the course of bladder carcinoma, such as a patient with advanced stage of disease. The improvement in chemotherapy alone or associated with radiological techniques for treatment in the primary organ may have prolonged the survival expectance for these patients. As such, the higher survival rates increase the risk of developing uncommon metastatic lesions, such as brain and lepto-meningeal metastases.

According to current medical literature, the incidence of CNS evolvement of disseminated TCC varies from $0.6 \%$ $8 \%,{ }^{9-11}$ and bladder carcinoma accounts for $0.5 \%$ of all intracranial metastases. ${ }^{8}$ Brain metastases as the first metastatic manifestation without evidence of recurrent or disseminated disease is extremely rare, with only few cases reported in the literature..$^{8-10}$ These lesions may be solitary or multiple, and may involve either the cerebral hemispheres or the cerebellum. ${ }^{12}$ Sarmiento et $\mathrm{al}^{13}$ states that metastasis to the frontal lobe seems to be the most common location of single lesions, followed by the temporal and parietal lobes. Moreover, cerebellar isolated involvement has been described in only four patients. 12,13

Meningeal carcinomatosis (MC) is a rare involvement of solid tumors, particularly seen in breast and lung cancer. There are only a few cases that describe MC secondary to TCC. A study performed by Anderson et al in 2003 analyzed a total of 359 patients with bladder cancer and found an incidence of $1 \%$ of brain metastasis; no patient developed MC. Two different articles published in 2010 and 2011 found, respectively, 22 and 30 cases of MC secondary to TCC. ${ }^{14,15}$

Some studies suggest that the incidence of central nervous system metastases is higher in patients who received aggressive initial treatment for bladder carcinoma. ${ }^{16,17} \mathrm{Be}-$ fore chemotherapy, metastases to the central nervous system occurred in less than $1 \%$ of patients. ${ }^{6}$ Supported by the fact that in the last decades the number of chemotherapeutic options increased as well as its effectiveness, a systemic control of the disease is frequently achieved. Moreover, better local control of the tumor with surgeries, associated or not with radiation therapy, extends the natural history of the disease, and consequently the number of late metastasis increases, such as intracranial lesions. ${ }^{18,19}$

A possible explanation for such a phenomenon is that the CNS may act as a sanctuary for residual tumor due to poor penetration of the chemotherapeutic agents through the blood-brain barrier. Thus, with better control of systemic disease and improved survival, CNS metastases as a late complication may become more common. ${ }^{11,12,17,20}$

This theory is advocated by many authors who believe that aggressive chemotherapy (in a regimen including methotrexate, vinblastine, doxorubicin, and cisplatin) prolongs the duration of tumor remission but does not cross the blood-brain barrier. ${ }^{4,11,20}$ In other words, the advent of the new chemotherapy regimen improved the primary and systemic control of the urinary bladder cancer, allowing patients to live long enough to develop cerebral metastasis. ${ }^{13}$

According to Rabadán et al, the median time between TCC diagnosis and its metastasis is 12 to 18 months, and usually the patient has multiple organs involved, not only the CNS. ${ }^{21}$ Our patient, on the other hand, was diagnosed with cerebellar lesion, and did not have any radiological sign or clinical symptom of systemic relapse. It has been suggested that abdominal and pelvic neoplasms may have a propensity for metastasis to the cerebellum, possibly as a result of retrograde dissemination through the vertebral venous system via Batson's plexus, bypassing the liver and lung, terminating in the intracranial venous sinuses at the foramen magnum. Such a mechanism may explain the finding of cerebellar metastasis, despite the absence of other systemic metastases. ${ }^{19,22}$

CNS metastases involve cerebral hemispheres in $80 \%$ of the cases, $5 \%$ in the brainstem and $15 \%$ in the cerebellum. ${ }^{11}$ According to tumor localization, the patient may complain of regular and unspecific headache, or suddenly develop seizures, neurologic deficit, or behavioral changes. ${ }^{21}$ Patients with cerebellar metastases often complain about occipital and/or frontal headaches and gait disturbances. ${ }^{22}$

Treatment of intracranial metastasis from TCC is not a simple and standardized procedure. From a general point of view, surgical excision followed by brain radiotherapy has been considered the mainstay treatment for brain metastases. ${ }^{4,5}$ However, therapeutic decision varies with the site and number of brain metastasis, and also with the systemic disease's control.

In the absence of other systemic metastases (extra cranial disease is controlled), patients with solitary CNS metastases from bladder carcinoma and good prognosis may benefit from surgical resection, ${ }^{12}$ followed, or not, by whole brain radiation therapy. If the patient has a solitary lesion, no bigger than $30 \mathrm{~mm}$, a therapeutic option is stereotactic radiosurgery, of which the results are comparable to regular surgery. ${ }^{17}$

External beam cranial irradiation may be a beneficial form of therapy in multiple brain metastasis and may offer effective palliation for patients with progressive systemic disease or multiple CNS metastases. ${ }^{12,17}$ It is important to emphasize that, historically, chemotherapy has not been an option for intracranial metastasis, given that most anti-tumor drugs do not cross the brain-blood barrier. ${ }^{8,17}$ However, Albers et al and Protzel et al reported good results of intracranial single or multiple metastases, treated with gemcitabine alone or associated with whole brain radiation. ${ }^{4,23}$ Gemcitabine is a small molecular size and low protein binding drug that appears to cross the blood-brain barrier. ${ }^{4}$ Therefore, these 
authors conclude that gemcitabine is a new chemotherapeutic option for palliative treatment of advanced TCC, especially in patients with poor performance status whose therapy goal is primarily palliative.

Brain metastases from TCC represent a serious and debilitating complication and survival is brief after diagnosis. The life expectance after diagnosis varies from 2 to 14 months, ${ }^{2,9,10}$ but most patients survive less than 6 months. ${ }^{17,19}$ However, long-term survival greater than 1 to 2 years is observed in up to $10 \%$ of patients with favorable prognostic factors, such as a solitary lesion, good Karnofsky performance status, and absent extra cranial disease. ${ }^{17}$ The patient herein described had a survival follow-up of 20 months, and died from systemic oncologic complications, with no signs of CNS tumor return. Therefore, a complete systemic investigation and metastasis resection, when possible, is indicated given that this treatment prolongs survival rates in this scenario.

\section{Conclusion}

Authors report a case of a patient with late metastasis from transitional cell carcinoma that underwent optimized oncologic therapy of the primary tumor. According to medical literature, the incidence of brain lesions secondary to bladder cancer has increased in the last few decades. However, no reports had been described in Brazilian literature, which makes this case unique in our country.

\section{References}

1 Babaian RJ, Johnson DE, Llamas L, Ayala AG. Metastases from transitional cell carcinoma of urinary bladder. Urology 1980; 16(2):142-144

2 Rosenstein M, Wallner K, Scher H, Sternberg CN. Treatment of brain metastases from bladder cancer. J Urol 1993;149(3):480-483

3 Steinfeld AD, Zelefsky M. Brain metastases from carcinoma of bladder. Urology 1987;29(4):375-376

4 Protzel C, Zimmermann U, Asse E, Kallwellis G, Klebingat KJ. Gemcitabine and radiotherapy in the treatment of brain metastases from transitional cell carcinoma of the bladder: a case report. J Neurooncol 2002;57(2):141-145

5 Erhamamcı S, Reyhan M, Altinkaya N. A case of brain and leptomeningeal metastases from urothelial carcinoma of the bladder. Rev Esp Med Nucl Imagen Mol [Internet]. SEMNIM 2014;33(5):290-2. Available from: http://linkinghub.elsevier. com/retrieve/pii/S2253654×13001893. Accessed on Sep 20, 2015

6 Davies BJ, Bastacky S, Chung SY. Large cerebellar lesion as original manifestation of transitional cell carcinoma of the bladder. Urology 2003;62(4):749
7 Lower WEWR. Primary carcinoma of bladder with metastasis to brain. Am J Med Sci 1924;167:434-437

8 Qasho R, Tommaso V, Rocchi G, Simi U, Delfini R. Choroid plexus metastasis from carcinoma of the bladder: case report and review of the literature. J Neurooncol 1999;45(3):237-240

9 Turgut M, Akyüz O, Kaçar F. Solitary cerebral metastasis from transitional cell carcinoma of the urinary tract. J Clin Neurosci 2007;14(11):1129-1132

10 Zigouris A, Pahatouridis D, Mihos E, et al. Solitary cystic cerebral metastasis from transitional cell carcinoma of the bladder. Acta Neurol Belg 2009;109(4):322-325

11 Sanchez Abraham M, Guagnini M, Sousa L, Romano L, Aleman A. Metástasis cerebral de carcinoma urotelial de vejiga. Neurol Argentina. 2011;3(3):186-188

12 Shamdas GJ, McLaren GD, Grimm T, Everson LK. Solitary cerebellar metastasis from transitional cell carcinoma of bladder. Urology 1992;40(1):50-53

13 Sarmiento JM, Wi MS, Piao Z, Stiner ES. Solitary cerebral metastasis from transitional cell carcinoma after a 14-year remission of urinary bladder cancer treated with gemcitabine: Case report and literature review. Surg Neurol Int 2012;3:82

14 Uncu D, Arpaci F, Beyzadeoglu M, et al. Meningeal carcinomatosis: an extremely rare involvement of urinary bladder carcinoma. Tumori 2010;96(2):352-354

15 Tadepalli S, Coleman T, Hacket LA, Liles GB. Carcinomatous meningitis: the natural history of successfully treated metastatic bladder cancer. Case Rep Oncol 2011;4(2):406-412

16 Bloch JL, Nieh PT, Walzak MP. Brain metastases from transitional cell carcinoma. J Urol 1987;137(1):97-99

17 Mahmoud-Ahmed AS, Suh JH, Kupelian PA, et al. Brain metastases from bladder carcinoma: presentation, treatment and survival. J Urol 2002;167(6):2419-2422

18 Anderson TS, Regine WF, Kryscio R, Patchell RA. Neurologic complications of bladder carcinoma: a review of 359 cases. Cancer 2003;97(9):2267-2272

19 Qasho R, Tommaso V, Rocchi G, Simi U, Delfini R. Choroid plexus metastasis from carcinoma of the bladder: case report and review of the literature. J Neurooncol 1999;45(3):237-240

20 Dhote R, Beuzeboc P, Thiounn N, et al. High incidence of brain metastases in patients treated with an M-VAC regimen for advanced bladder cancer. Eur Urol 1998;33(4): 392-395

21 Rabadán AT, Diez B, Martínez AM, et al. Consenso para el tratamiento de las metástasis cerebrales. Rev Argent Neurocir 2006;20(4):179-193

22 Fadul C, Misulis KE, Wiley RG. Cerebellar metastases: diagnostic and management considerations. J Clin Oncol 1987;5(7): 1107-1115

23 Albers P, Siener R, Härtlein M, et al; German TCC Study Group of the German Association of Urologic Oncology. Gemcitabine monotherapy as second-line treatment in cisplatin-refractory transitional cell carcinoma - prognostic factors for response and improvement of quality of life. Onkologie 2002;25(1): 47-52 